\title{
Minority Muslims and freedom of religion: learning from Australian Muslims' experiences
}

Syamsul Arifin

University of Muhammadiyah Malang

E-mail:syamsarifin@umm.ac.id

Hasnan Bachtiar

The Australian National University, Australia

E-mail: u6292460@anu.edu.au

Ahmad Nur Fuad

State Islamic University, Sunan Ampel, Surabaya

E-mail: ahmadnurfuad@yahoo.com

Tongat

University of Muhammadiyah Malang

E-mail: tongat_umm@yahoo.co.id

Wahyudi

University of Muhammadiyah Malang

E-mail:wawahyudi@yahoo.com

DOI: 10.18326/ijims.v9i2.295-326 


\begin{abstract}
This article aims at diagnosing the development of Ummah while Muslims are living as minority in Australia. Through a sociological approach, qualitatively, some issues considered in understanding the development are practices of secularism, multiculturalism and protection of human rights. This academic framework in comprehending the development might be claimed as a new trajectory of sociological exploration. Accordingly, this study is proposed to become a preliminary research on Muslims' freedom of religion living in secular country. This article finds that Australia is a state that consistently has protected its citizens' freedom of religion and the Australian government, in dealing with social and religious issues, and law enforcement, has worked professionally. However, Muslims have faced challenging realities of cases of discrimination coming from fundamentalist Christians. The cases, indeed, can be mitigated through inter-religious dialogue and cooperation. This article argues that, so far, the development of Ummah in the country has been running well. Under the protection of a secular state, minority Muslims in Australian multicultural societies can enjoy their freedom of religion. Practices of inter-religious tolerance are stronger than the tensions and conflicts have happened.
\end{abstract}

Artikel ini bertujuan untuk mendiagnosa kondisi pembangunan umat ketika kaum Muslim hidup sebagai minoritas di Australia. Melalui pendekatan sosiologis, secara kualitatif, pelbagai isu yang dipertimbangkan adalah praktik sekularisme, multikulturalisme dan penegakan HAM. Kerangka kerja yang demikian dalam memandang pembangunan umat, dapat diklaim sebagai hal yang baru. Karena itu, studi ini diusulkan sebagai studi pendahuluan mengenai elaborasi sosiologis terhadap kebebasan beragama minoritas Muslim yang hidup di negara sekular. Artikel ini menemukan bahwa Australia adalah negara yang secara konsisten melindungi kebebasan beragama warga negaranya dan pemerintahnya bekerja secara profesional terutama dalam penegakan hukum. Tetapi, kasus-kasus diskriminasi masih terjadi, terutama oleh Kristen fundamentalis terhadap kaum Muslim. Tentu saja hal itu dapat dimitigasi melalui dialog dan kerjasama antar agama. Artikel ini berargumentasi bahwa, sejauh ini kondisi pembangunan umat berjalan dengan baik. Di bawah perlindungan negara sekular, Muslim minoritas yang hidup di tengah masyarakat multikultural dapat menikmati kebebasan 
beragama. Praktik-praktik toleransi yang ada, lebih kuat ketimbang tensi dan konflik antar-agama yang terjadi.

Keywords: Minority Muslims; Freedom of religion, Human rights; secularism; Multiculturalism

\section{Introduction}

While Indonesian Muslims are recognised as majority, in Australia they are minority. The latter leads to questions such as how does the position of ummah (community of believers) when Muslims are living as minority in a Western secular country like Australia? Does Australian government guarantee their freedom of religion?

Both questions closely relate to the crucial issue of freedom of religion. These questions would be ensuring, whether the principle of "everyone has the freedom, either alone or in community with others, in public or private, to manifest his or her religion or belief in teaching, practice, worship and observance" ${ }^{1}$ has been fulfilled by the state or has not. Consequently, the very possible answers of the questions determine a theoretical assumption of the position of religious minority groups in a state claiming that governmental authorities tend to respect majority and guarantee the public order, instead of protecting the freedom of religion of their citizens (especially minority). ${ }^{2}$

This article arguably states that Australia as a secular-multicultural state has protected, respected and fulfilled the freedom of religion of its all

\footnotetext{
${ }^{1}$ Tore Lindholm, W. Cole Durham, Jr., and Bahia G. Tahzib-Lie (eds.), Facilitating Freedom of Religion or Belief: A Deskbook, Leiden: Koninklijke Brill NV, 2004, xxxviii.

${ }^{2}$ Manfred Nowak and Tanja Vospernik argue that certain restrictions in expressing the freedom of religion are legally permissible. Their applicability depends on certain socio-cultural and political contexts, however. It has been potentially coloured by tensions and conflicts. See further in Nowak and Vospernik, "Permissible Restriction on Freedom of Religion or Belief," in Tore Lindholm, W. Cole Durham, Jr., and Bahia G. Tahzib-Lie (eds.), Facilitating Freedom of Religion or Belief: A Deskbook, Leiden: Koninklijke Brill NV, 2004, 147-172.
} 
citizens. Accordingly, from the Muslims' perspective, Australia supports the development of Ummah. Muslims, although they are minority, they have gained benefits due to both the state law enforcement and living in a societal context that is secular and multicultural. Yet, they have been challenged by cases of discrimination. The cases had happened due to the roles played by political actors in a circle of another conservative religious minority group. Systematically, this article covers a brief discussion on the rights of the freedom of religion, Muslims in Australia as a minority, becoming Muslims in the secular-multicultural country, freedoms of religion in the secular state and a Muslim intellectual's thought of the freedom of religion.

\section{The right to the freedom of religion}

In general, the right to the freedom of religion is an essential right of individual to freely "believe or does not believe in" or "change" and "express" a religion or belief in the public with the state protection. ${ }^{3}$ It consists of two kinds of freedom: internal and external freedom. While the former means everyone has right to choose, adhere or not, change one's religion or belief, the latter is to express, manifest, propagate and assemble his/her religion or belief. While the former is likely rare to trigger societal problems, the latter relatively becomes an essential factor of the clash of perceptions and conflicts.

The latter, as a key factor of societal problems deals with the matter of manifestation, propagation and creation of assembly. ${ }^{4}$ In terms of

${ }^{3}$ Johannes A. Van Der Ven, Human Rights or Religious Rules?, Leiden: Brill, 2010, 279; Syamsul Arifin, Attitudes to Human Rights and Freedom of Religion or Belief in Indonesia, Yogyakarta: Kanisius, 2010, 23; Syamsul Arifin, "Indonesian Discourse on Human Rights and Freedom of Religion or Belief: Muslim Perspectives," Brigham Young University Law Review, Volume 1, Issue 3 (2012): 800.

${ }^{4}$ See United Nations, The Declaration on the Elimination of All Forms of Intolerance and Discrimination Based on Religion or Belief, 1981. Accessed April 25, 2018. http://www.un.org/ documents/ga/res/36/a36r055.htm. 
manifesting religious doctrines, it allows one to do and to obey religious practices or rituals either privately or publicly. Meanwhile, the propagation encompasses rights to teach, to train, to make religious claims and to proselytise others. The freedom of religion also deals with principles of religious tolerance, non-discrimination and equality. Regarding the creation of an assembly, it enables individuals to meet each other in religious meetings.

Both the internal and external freedom are legally protected by the law. According to the Article 18 of the Universal Declaration of Human Rights (UDHR), "Everyone has the right to freedom of thought, conscience and religion; this right includes freedom to change his religion or belief, and freedom, either alone or in community with others and in public or private, to manifest his religion or belief in teaching, practice, worship and observance. ${ }^{5}$ In the Article 18 of the International Covenant on Civil and Political Rights (ICCPR) states that "No one shall be subject to coercion which would impair his freedom to have or adopt a religion or belief of his choice." 6

Interpretation on the right to the freedom of religion, however, has been deliberately contested. Consequently, although some countries ratified international documents of this right, they have different ways in implementing it because there are dynamics and complexities of statepeople relations. ${ }^{7}$ The implementation depends on the state maturity in

${ }^{5}$ United Nations, The Universal Declaration of Human Rights, 1948. Accessed April 25, 2018. http://www.un.org/en/universal-declaration-human-rights/.

${ }^{6}$ Similar voice is stated in the Article 27 of ICCPR that the rights "to profess and practice their own religion" should not be denied. See United Nations, International Covenant on Civil and Political Rights, 1966. Accessed April 25, 2016. https://www.un.org/ruleoflaw/blog/ document/international-covenant-on-civil-and-political-rights/. In another articulation, it is emphasised that "religion or belief for each believer is one of the fundamental elements of life that should be assured and respected." United Nations, The Declaration on the Elimination of All Forms of Intolerance and Discrimination Based on Religion or Belief, 1981.

7Ali Mirmoosavi, "The Qur'an and Religious Freedom" in Bas de Gaay Fortman, Kurt 
understanding its doctrines of polity, continuity and discontinuity of its historical experience and its development of civilizational aspects. Thus, dimensions of freedom of religion seem to be not fully acknowledged by all countries due to restrictions made by some based on their political arguments. ${ }^{8}$

\section{Muslims in Australia as a minority}

The presence of Muslims in Australia might be traced to the mid of $19^{\text {th }}$ century. The number of people coming into this country sharply decreased due to the Establishment of the Australia Commonwealth and the White Australia Policy in 1901. This policy was intended to limit the wave of Muslims immigrants that had moved from the Middle East to Australia. Under the 1901 Immigration Restriction Act, Muslims from Afghanistan, Lebanon and other Asian countries were often refused to apply for their citizenship status. The policy was claimed to maintain the homogeneity of Australian cultures and national interests. ${ }^{9}$ Muslims were assimilated with more widely Australian community or returned to their original countries. ${ }^{10}$

Martens, and MA Mohamed Salih (eds) Hermeneutics, Scriptural Politics, and Human Rights, New York: Palgrave Macmillan, 2009; Abdullah Saeed and Hassan Saeed, Freedom of Religion, Apostasy and Islam, Burlington: Ashgate, 2004, 10-12.

${ }^{8}$ Ali Mirmoosavi, "The Quran and Religious Freedom..., 127-128.

${ }^{9}$ Fethi Mansouri, "Citizenship, Identity, and Belonging in Contemporary Australia," in Shahram Akbarzadeh and Samina Yasmeen (eds), Islam and the West: Reflections from Australia, Sydney: UNSW Press, 2005, 149; Ahmad Fuad Fanani, "Menjadi Muslim Minoritas di Negara Sekuler: Refleksidari Australia," Prisma, Volume 29 (2010), 73; Michael Humphrey, "An Australian Islam?: Religion in The Multicultural City," in Abdullah Saeed and Shahram Akbarzadeh (eds.), Muslim Communities in Australia, Sydney: UNSW Press, 2001, 35-36; Bilal Cleland, The Muslim in Australia: A Brief History, Melbourne: Islamic Council of Victoria, 2002; Samina Yasmeen, "Understanding Muslim Identities: From Perceived Relative Exclusion to Inclusion," Centre for Muslim State and Societies, University of Western Australia, May 2008, 5; Scott Poyning and Victoria Mason, "The Resistible Rise of Islamophobia: Anti-Muslim Racism in the UK and Australia Before 11 September 2001”, Journal of Sociology, Volume 43, Number 11 (2007), 66; Salih Yucel, "Is Islam Part of the Problem or Solution: An Australian Immigrant Experience?” Turkish Journal of Politics, Volume 2, Number 1 (2011), 100.

${ }^{10}$ Anita Harris and Kim Lam, "Youth Participation in 'Post $\$ Secular' Times: Young Muslim 
Against the policy, in fact, numbers of Muslims in Australia have increased and the government acknowledges them. However, the Ummah in the country does not always enjoy its freedom of religion. Muslims have faced challenges such as discrimination, racism and stereotypes. ${ }^{11}$ In 1960s, Muslim population in Australia grew up. Many see that the 1970 1990s decade as a relatively positive period for Muslims in this country. The growth of Islam was an effect of the multiculturalism policy and the elimination of the White Australia Policy. Moreover, the booming number of Muslim students and the non-discriminative immigration policy has brought Muslims from various backgrounds into Australia. Following this, the establishment of Islamic organisation, the development of a number of important Islamic institutions such as schools, mosques, and the increasing interests among Australians with European background in Islam have contributed to the establishment of Muslim community in Australian major cities. ${ }^{12}$ The consolidation of Islam as an important part of the Australia religious structure was continuing, although since the end of 1990s some degradation took place.

The long presence of Muslims in Australia had not been debated due to some shocking events occurring at the end of 1990s and on. According

and Buddhist Practitioners as Religious Citizens," The British Journal of Sociology, Volume 70. Issue 2 (2019): 627-646.

${ }^{11}$ James Barry and Ihsan Yilmaz, "Liminality and Racial Hazing of Muslim Migrants: Media Framing of Albanians in Shepparton, Australia, 1930-1955," Ethnic and Racial Studies, Volume 42, Issue 7 (2019): 1168-1185.

${ }^{12}$ Abdullah Saeed, Islam in Australia, Sydney: Allen \& Unwin, 2003, 208-9; Abdullah Saeed, "Muslim Australians: Their Beliefs, Practices and Institutions," Department of Immigrant and Multicultural and Indigenous Affairs and Australian Multicultural Foundation in Association with the University of Melbourne, 2004; Sven Alexander Schottmann, "Being-Muslim in Australia, ca. 2013," Islam and Christian-Muslim Relation, Volume 24, Number 4 (2013); Rachel Busbridge, "It's Just Your Turn: Performing Identity and Muslim Australian Popular Culture," Islam and Christian-Muslim Relation, Volume 24, Number 4 (2013); Rachel Woodlock, "Praying Where They Don't Belong: Female Muslim Convert and Access to Mosque in Melbourne, Australia," Journal of Muslim Minority Affair, Volume 30, Number 2 (2010). 
to Abdullah Saeed, the appearance of "Hansonism" (related to a politician named Pauline Hanson), ${ }^{13}$ the asylum seekers problem (most of them among others were Muslims), the 9/11 incident and harsh convictions of the federal government on handling them, and the 9/11 incident had shaken the core of the arrival of Muslims in Australia. ${ }^{14}$ Hansonism, Saeed maintains, was not targeted at Muslims, but an attitude towards antimigration had triggered an antipathy to non-European migrants, including Muslims. ${ }^{15}$ An indirect delineation of the asylum seekers with Muslim background as potential or unbelievable terrorists, after the 9/11 incident, had fuelled more feelings of anti-Muslims among some of Australians. ${ }^{16}$

In this context, Islam and the West are generally described as two homogenous entities on the tract where they are colliding one another. Muslims are considered as basic threats to the existence of the west liberal values. As a result, the Muslim community is regarded as an enemy within. Apart from this condition, it seemed that most Australian did not show any hostility to Muslims. At all levels of Australian community, there

\footnotetext{
${ }^{13}$ Herself is a right wing politician, a figure of One Nation, a right wing party with conservative and anti-multiculturalism tendency. See further Jeffrey Lewis, Philip Pond, Robin Cameron, and Belinda Lewis, "Social Cohesion, Twitter and Far-Right Politics in Australia: Diversity in the Democratic Mediasphere," European Journal of Cultural Studies, Volume 22, Issue 5-6 (2019), 958-978.

${ }^{14}$ Saeed, Islam in Australia..., 208-9; Adrian Cherney and Kristina Murphy, "Being a 'Suspect Community' in a Post 9/11 World - The Impact of the War on Terror on Muslim Communities in Australia," Criminology, Volume 48, Issue 4 (2016), 480-496.

${ }^{15}$ See also Donald Reid, "Sharing the Halal Snack-Pack: Multiculturalism as NeoAssimilation in Australia," Journal of Media and Cultural Studies, Volume 22, Issue 1 (2019), $77-92$.

${ }^{16}$ Shahram Akbarzadeh, "The Muslim Question in Australia: Islamophobia and Muslim Alienation," Journal of Muslim Minority Affairs, Volume 36, Issue 3 (2016), 323-333; Mario Peucker, "Islamophobia and Stigmatising Discourses: A Driving Force for Muslim Active Citizenship?" in Esposito J., Iner D. (eds.) Islamophobia and Radicalization, Cham, Switzerland: Palgrave Macmillan, 2019: 245-264; Cal Colic-Peisker, Masha Mikola and Karien Dekker, "Religious Visibility: Perceptions and Experiences of Residents in Two Muslim Concentration Suburbs in Melbourne, Australia”, Ethnic and Racial Studies, Volume 42, Issue 15 (2019), 2743-2762.
} 
is an extraordinary tolerance, if not acceptance, to Muslims as a part of Australia. The Australian legal frame gives some additional protection. Australians is the most tolerant and hospitable people for the Ummah in the Western world. ${ }^{17}$

The most important challenge for Muslim leaders in new environment, however, is to eliminate any prejudice among Australians that Muslims are anti-West, anti-Australia and are not really parts of Australia. ${ }^{18}$ Saeed states that Muslim leaders should face and explain such a negative opinion. Though many Muslims, as individuals, have made some efforts to explain or to counter this negative view, the efforts are sporadic and ad hoc in nature, and there are many things to do in this area in more systematic and strategic ways. Muslim leaders, therefore, have some obligations to explain the problems to Australians widely, and to provide balanced views. ${ }^{19}$

As part of responses to this situation, Australian Muslims built a closer relationship with communities of other religions in Australia in order to make some cooperation with them concerning various issues such as religious and social harmony. Muslim leaders should find ways of not emphasising the ethnical or national differences but emphasising the identification of religion or Australia, leading into further consolidation form Australian Muslims where their loyalty is to Australia, instead of to other nations in other places.

To cope with various challenges Australian Muslims have, Saeed argues, it is important to develop a well-trained religious leadership in the

\footnotetext{
${ }^{17}$ Saeed, Islam in Australia..., 210; Mansouri, "Citizenship, Identity and Belonging in Contemporary Australia..., 159.

${ }^{18}$ Kristina Murphy, Natasha S. Madon and Adrian Cherney, "Reporting Threats of Terrorism: Stigmatisation, Procedural Justice and Policing Muslims in Australia," Policing and Society, An International Journal of Research and Policy (2018), 1-17; Fethi Mansouri and Matteo Vergani, "Intercultural Contact, Knowledge of Islam, and Prejudice against Muslims in Australia”, International Journal of Intercultural Relations, Volume 66 (2018), 85-94.

${ }^{19}$ Saeed, Islam in Australia..., 210.
} 
discipline of the classical Islam, but at the same time is also well-versed in modern issues and familiar with Australian community, cultures and history. ${ }^{20}$ Muslims elites should be able to communicate in English with wider Muslim audience who are born and grown up in Australia and in the spirit of Australia. The leadership should be able to show norms ad values of Islam in understandable form and relevant with the increasing number of Australian Muslims. For them, an idea of becoming Australian may not collide with an idea of becoming Muslims.

Saeed acknowledges, solving such problems is not an easy. However, those who are real Muslims and Australians certainly may solve them. Although it represents many manifestations of Islam all over the world, Islam in Australia is being formed by values, norms, and practices prevailed among Australian. The values basic to them are accommodated in what is called Islam. An Australian-born new generation of Muslims is the most enthusiastic supporter to this view. For them, Islam is compatible with modern values that may be meaningful to and relevant with their lives in Australia. ${ }^{21}$

This long history of Muslims in Australia as a minority will be enriched by more current process of societal formation in Australia. This chapter will explain possibilities of gaining advantages of the fulfilment of the right to the freedom of religion or belief while Muslims are living in this more secular and multicultural country.

\section{Becoming Muslims in the secular multicultural country}

The estimated number of 476.290 Australian Muslims has come from more than 70 countries with various languages and cultures. In this context, religion is a uniting factor since almost all migrants coming to Australia

\footnotetext{
${ }^{20}$ Saeed, Islam in Australia..., 208-211.

${ }^{21}$ Saeed, Islam in Australia..., 208-211.
} 
from countries in which their civil law, especially family law, is regulated by the Islamic law, which is modified by the state law. ${ }^{22}$ In Australia, Muslims are not considered as an exclusive religious community, but as citizens or populations who comply with national law. However, becoming a Muslim in a secular country such as Australia does not automatically make him or her possess the same comfort like those living in a Muslim country. In observance, for example, there are a number of regulations a Muslim should obey in order not to bother the comfort of non-Muslims. In their daily life, moreover, they should also adapt to and acculturate with local cultures. ${ }^{23}$

After adopting the White Australian Policy in 1901 marked by the arrival of white immigrants, in 1915, an important debate on the cultural assimilation and languages in Australian people occurred. For that reason, an idea on various cultures or multiculturalism became important from 1950s to 1970s. In 1970s and 1980s, multiculturalism is understood as acknowledgment of another culture. Saeed expressed that "If you are an immigrant bringing with you a certain culture, you and your culture are recognized. We and they acknowledge our and their cultures, but the

\footnotetext{
${ }^{22}$ Jamila Hussein, "Muslim Family Law in Australia: Conflicting or Compatible," in Samina Yasmeen (ed.), Muslims in Australia: The Dynamics of Exclusion and Inclusion, Melbourne: Melbourne University Press, 2010, 206; Salim Farrar, "Profiting from Shari'a: Islamic Banking and Finance in Australia," in Adam Possamai, James T. Richardson, Bryan S. Turner (eds.), The Sociology of Shari'a: Case Studies from around the World, London: Springer, 2015, 273; Abdul Malik Mirza and Abdel-Karim Halabi, "Islamic Banking in Australia: Challenge and Opportunities," Journal of Muslim Minority Affairs, Volume 23, Number 2 (2003); Kevin M. Dunn, Natascha Klocker and Tanya Salaby, "Contemporary Racism and Islamophobia in Australia: Racializing Religion,” Ethnicities, Volume 7, Number 4 (2007), 565; Liza Hopkins, "Muslim Turks and anti-Muslim Discourse: The Effects of Media Constructions of Islamic and Arabic in Australia," Australian Journal of Communication, Volume 35, Number 1 (2008), 48.

${ }^{23}$ Ahmad Fuad Fanani, "Menjadi Muslim Minoritas di Negara Sekuler: Refleksi dari Australia," Prisma, Volume 29 (2010), 73. The Australian case needs to be compared with another case such as what had happened in Britain. See Amika Wardana, "Institutionalising Diasporic Islam: Multiculturalism, Secularism and the Integration of Muslim Immigrants in Britain," Indonesian Journal of Islam and Muslim Societies, Volume 3, Number 1 (2013), 31-72.
} 
existing law still considers the basic culture." ${ }^{24}$ The basic values considered as fundamental in a country cover, for example, justice, equality, freedom of religion, human rights, prevailing law, and the use of English.

However, in fact, some criticisms on social practices based on the idea of multiculturalism appeared. Saeed also shows an example that "When someone causes some fragmentation among the existing cultures, it is also important to think, actually what culture exists in Australia is Islam as a religion compatible with fundamental values of the state such as human rights, gender equality, social justice, and legal enforcement." 25 According to Saeed, furthermore, some Muslims may consider gender discrimination as not a serious matter, or that no freedom of religion is a good matter ${ }^{26}$ However, the basic conception in Islam emphasises that gender equality and freedom of religion are good. Both ideas are very Islamic in nature. Those coming from Saudi Arabia or Iran, according to Saeed, will not been seen as "Muslims" but as citizens. ${ }^{27}$

In a secular and multicultural country like Australia, however, discrimination is felt. The attitude of anti-multiculturalism, or even anti-Islam shown by majority is an example. Bilal Cleland, the author of "The Muslims in Australia: A Brief History" shares this experience. Cleland told a story about Scott Morrison, an officer in the Ministry of Immigration and Border. Cleland perceives the position Morrison held in the Australian Liberal Party threatened Muslims. Scott Morrison is a follower of fundamentalist Christian, educated in the Jewish studies. There is a small group of fundamentalist Christian attacking Muslim community. ${ }^{28}$

\footnotetext{
${ }^{24} \mathrm{An}$ interview with Abdullah Saeed, Melbourne University.

${ }^{25}$ An interview with Abdullah Saeed, Melbourne University.

${ }^{26} \mathrm{An}$ interview with Abdullah Saeed, Melbourne University.

${ }^{27}$ An interview with Abdullah Saeed, Melbourne University.

${ }^{28} \mathrm{An}$ interview with Bilal Cleland in Islamic Council of Victoria, Melbourne.
} 
In line with Cleland, Philip Flood, an ex-ambassador of Australia, in Saudi Arabia, Pakistan, Vietnam, Brunei Darussalam and Indonesia saw that some discriminations still exist as shown by some fundamentalist Christian. ${ }^{29}$ This attitude reflected a strong religious fanaticism. The local government elected usually supports the Muslim community to strive against fanatic groups of religions, however. In a democratic system, if a fundamentalist Christian is very strong, all lawsuits may be indicted into the federal court and each discrimination is not allowed.

Cleland states that discriminations are not conducted by local governments but by the circle of fundamentalist Christian. ${ }^{30}$ They organised groups of Christians who tend to be extreme. According to him, Muslims may give opinions, may speak through television, also may give their opinions in front of the Parliament. Some fundamentalist Christians tend to attack minority groups. ${ }^{31}$ According to Aykan, an immigrant from Turkey, a group of Evangelists did not attack minorities, but merely wanted to be involved in dialogues or debates. ${ }^{32}$ He firmly stated, "it is not Church but media that attack Muslims. There are radios, televisions, and the like." 33 Shahram Akbarzadeh, a Muslim academic in Australia, stated that in almost in every case, there are many communities working in Australia. ${ }^{34}$ For instance, in the Muslim Australian-Iran community, they

\footnotetext{
${ }^{29}$ An interview with Phillip Flood.

${ }^{30} \mathrm{An}$ interview with Bilal Cleland in Islamic Council of Victoria, Melbourne.

${ }^{31}$ An interview with Philip Flood in Islamic Council of Victoria, Melbourne.

${ }^{32} \mathrm{An}$ interview with Nail Aykan.

${ }^{33}$ An interview with Nail Aykan.

${ }^{34}$ Shahram Akbarzadeh is a professor in International Relations in University of Melbourne, Australia. He is the editor of Islam and Human Rights in Practice: Perspective Across the Ummah. He is also director of the National Centre of Excellence for Islamic Studies, the University of Melbourne. His interest of study includes Islam in Australia, Middle East and Middle Asia. He wrote (with Abdullah Saeed) books, Muslim Communities in Australia, Sydney: University of New South Wales, 2001; Uzbekistan and the United States, London: Zed Books, 2005; Islam and Globalization, 4 volumes, London: Routledge, 2006; and (with Kylie Baxter) US Foreign Policy in the Middle East, London: Routledge, 2008.
} 
talked about the position of Imam, contra-terrorism and radicalisation.

According to Saeed, some tensions between Muslims and Evangelists do not always occur. It should be noted that, like Muslims, Evangelists are also minority groups. ${ }^{35}$ The majority, Christians, do not support the Evangelists. This also happens to Muslim. For example, the Muslim majority is reluctant to support the agenda of Evangelist Muslims (radical Muslims).

Aykan, the director of the Islamic Council of Victoria, Melbourne, stated that in Melbourne, there are 50 places of worship, but there only one mosque. Certainly it is not sufficient. He argues, it needs $\$ 5$ million to procure a mosque. The state protects all religions in Australia, they have the same right. All of them possess the same right before the law. No discrimination is allowed at all, and no difference is permitted. Church, for example, have right, like the other groups of religions. But, again in Melbourne, the cost needed for managing the places is very high. The mosque in Melbourne was built in 1979 which was previously a house bought at the price of $\$ 300,000$, and located at a main road. The price now may reach $\$ 5$ million. ${ }^{36}$

According to Aykan, the existing mosques are inadequate to accommodate all the Muslims who pray together. To solve the problem, the praying activities are made in two sessions. The Idul Fitri (a feast celebrating the end of fasting period) and Idul Adha (the day that commemorates the sacrifice of Ismail by Ibrahim) are held in open space. Aykan proposes a permission to hold the Idul Fitri or Idul Adha praying in the parks to the Secretary of the City, free of charge. However, there is also a group of Muslims asking some contributions from its members for

\footnotetext{
${ }^{35} \mathrm{An}$ interview with Abdullah Saeed.

${ }^{36} \mathrm{An}$ interview with Nail Aykan. He is an immigrant from Turkey. He moved into Australia because he followed his parents, due to economic reasons. His family came to Australia to get jobs. He, himself is a manager.
} 
certain expenses. In this context, according to Aykan, the state supports the ummah of religion, and no discrimination occurs. It is almost impossible to find any discrimination. Aykan states that in Indonesia it is possible to find some discrimination, where one area discriminates another. However, Australia is an exception, since this country adopts a multiculturalism view, since its society is multicultural. ${ }^{37}$

As the representation of minority group, Aykan and the institution he leads, expect that there is tolerance without any exception among religions. He informs that the local government has given good services, and has noted that there is a multicultural need in the society. They try to accommodate multiculturalism aspirations, though there are still some people who are reluctant to it. In certain contexts, Muslims might be blamed and therefore, they face some discriminations. Consequently, according to Aykan, Muslim community have been trying to solve the discrimination. The prominent figures and leaders came to the Political Counsellors, and expressed their feelings openly. It is stated that "if the aspiration is expressed to the authorized party, it will be solved. Therefore any dangerous incident may avoid. Etiquettes of Muslims' behaviours should be based on professionalism." 38

Australia is a secular country. It does not give any assistance to schools under the name of religion. In this relation, according to Saeed, Islamic Studies is not taught in public schools. They do not teach religions specifically. The religion education is taught at private schools, such as those managed by communities of Muslim, Christian, Jew, Hindu, Buddha, Sikh, Evangelist, and the like. Moreover, each community provide facilities for the religion education once a week. Government finances school teachers to perform extra-curricular activities. It is them who teach

\footnotetext{
${ }^{37}$ An interview with Nail Aykan, Melbourne.

${ }^{38}$ An interview with Nail Aykan, Melbourne.
} 
religions and languages. However, it does not mean that it does not give any support to religious schools. Although they did not say that they are Islamic schools, but they usually call themselves as minority college.

\section{Freedom of religion in the secular state}

As a secular state, Australia gives freedoms of religion to Muslim minority group. According to Aykan, the Church can never intervene the state and the state cannot intervene the Church (religion). Thus, secularism means freedoms to practice any observances. In Aykan's view, secularism is not undermining religions, but observances, meaning protecting the followers of religions. ${ }^{39}$

How does this secularism being constructed? In legal perspective, this state absolutely obeys the international human rights law. It is a loyal supporter of the Universal Declaration of Human Rights (UDHR) 1948. In addition, in 1980 it ratified International Covenant on Civil and Political Rights (ICCPR) 1966, ${ }^{40}$ the most important international legal document that protects the right to the freedom of religion. It protects, respects and fulfils its citizens' right to the freedom of religion, though with some limitations while externally this freedom should be expressed, such as "manifestation of religion or belief must not may amount to propaganda for war or advocacy of hatred that constitutes incitement to discrimination, hostility or violence." ${ }^{41}$ In addition, regarding the issue of the clash of perceptions and the possibility of the emergence of interreligious conflicts, it also supports the importance of interreligious

\footnotetext{
${ }^{39} \mathrm{An}$ interview with Nail Aykan, Melbourne.

${ }^{40}$ Australian Human Rights Commission, "Chart of Australian Treaty Ratifications as of May 2012.” Accessed April 22, 2018. https://www.humanrights.gov.au/chart-australian-treatyratifications-may-2012-human-rights-your-fingertips-human-rights-your.

${ }^{41}$ Australian Human Rights Commission, "Freedom of thought, conscience and religion or belief." Accessed April 22, 2018. https://www.humanrights.gov.au/freedom-thoughtconscience-and-religion-or-belief.
} 
tolerance. In this matter, Australia states that "Official or majority status of a religion or belief must not disadvantage adherents of other religions or beliefs." ${ }^{\prime 2}$ In the official media release of the Australian Prime Minister (14 December 2017), confidently mentions that, "Australia is the most successful multicultural society in the world. Right at the heart of our success as a free society is freedom of religion. It is a fundamental national value, recognised in the Constitution." ${ }^{43}$ Therefore, in the perspective of law, there is no question that Australia as a secular state is a strong supporter of the freedom of religion.

Due to the state legal position, then it manifests in state policies that significantly have influenced Australian society. For example, although Australia is secular, the government provides funds for mosques, churches and temples. It provides scheme of grant for managers and social workers, instead of for dakwah (missionary endeavours). "Since we organise this multicultural communities of religions, the government expects peace among the communities," said Aykan. In Melbourne, there are some organisations such as the organisation of cross-belief dialogues. Aykan is a member of a group of cross-belief dialogue. All followers of religions such as Buddha, Christian, Jew, Sikh and the like become the members of the group. According to Aykan, each person has a right to follow a religion one believes in, "lakum dinukum waliyadin". It is simple. Belief may not be coerced. In Australia, a mosque is not for any missionary endeavours. People merely come to this place to pray.

Furthermore, Aykan states that "We simply provide leadership and advocacy. It is not religion, but community based." ${ }^{44}$ In this context,

\footnotetext{
${ }^{42}$ Australian Human Rights Commission, "Freedom of thought, conscience and religion or belief."

${ }^{43}$ Prime Minister, "Protecting Freedom of Religion in Australia: Media Release 14 December 2017.” Accessed April 22, 2018. https://www.pm.gov.au/media/protecting-freedomreligion-australia.

${ }^{44}$ An interview with Nail Aykan, Melbourne.
} 
Muslim counsellors work in the community sector, instead of in the religious one. They do not work to promote missionary endeavours, but to build a relation with other communities in order to reach common understandings and awareness towards others. They work for the police, the government, not for the religions. Therefore, the program of Islamisation in Australia is very small and insignificant. Those working for "Islamisation" usually do it via social media such as Facebook. For example, they spoke about hijab (veil) and the like. When they worked in the streets, in the classroom, they talked about Ramadhan (fasting month), it seemed that they were trying to protect Muslims. However, according to Aykan, this is not important at all..$^{45}$

In Aykan's opinion, living in a secular country such as Australia is more comfortable. He expresses that "As real Muslims, we are really comfortable with this country. I am a Muslim, but I am a citizen of this country. No problem. There are some parties trying to promote any conflicts between Australians and Muslims. But we do not work for that. We work for humanity and the poor." ${ }^{\prime 6}$ For instance, Aykan and his institution has charity boxes. It is from the charity boxes that his institutions are able to buy some foods for the poor. When Aykan was asked about his opinion about agnostic groups, he said "lakum dinukum waliadin'. If you are good, if you are not extreme, it is the right choice. I believe in God, here after, hell, and paradise, and at the end you will get some surprises. But for Agnostics, no problem, but you should take all the risks." ${ }^{47}$

To some extent, the state attitude toward the fulfilment of the right to the freedom of religion, its legal bodies and regulations, practices secularism in a multicultural country, all of them have shaped, conditioned and determined Muslims' perspective on the freedom of religion. In this

\footnotetext{
${ }^{45}$ An interview with Nail Aykan, Melbourne.

${ }^{46}$ An interview with Nail Aykan, Melbourne.

${ }^{47}$ An interview with Nail Aykan, Melbourne.
} 
context, it is important to understand a Muslim intellectual's thought of this issue as a particular representation of Ummah in Australia.

\section{A Muslim intellectual's thought of the freedom of religion}

One of Muslim intellectuals in Australia pays serious attention to issues on Islam and freedom of religion in the modern context is Abdullah Saeed. Himself is a professor at University of Melbourne, who comes from a traditional religious family. He was once educated in the scholarly tradition of Classical Islam and in Arabic in Arabian Saudi, then in the modern (West) scholarly tradition.

For him, the statement in article 18 on the rights to "change... religion and belief" is very important, because the verse touches upon a controversial area on apostasy in Islam. He suggests that the right to the freedom of religion "might be the oldest human right internationally acknowledged." ${ }^{48}$ However, this freedom is seen to break a teaching related to apostasy in Islam. This has an area for fierce debates since the treatment to the apostasy "is essentially not different from its conceptualisation in the second century of Islam up to now." ${ }^{49}$ It is an changeable law, and it is explained that the punishment is hudud.

Regarding the issue of hudud, the scale of the punishment is debated among the Muslim jurists ('Ulama), since it is not based on the Quranic legal products, but the Prophetic tradition (hadith).$^{50}$ In Islam, the debate on the apostasy is focussed on the cruelty of the punishment, instead on the legality of the action. Some 'Ulama claim that there is no base in the Quran to apply the capital punishment for apostasy and moreover, the freedom of religion is the basic principle of Islam. Saeed states that

\footnotetext{
${ }^{48}$ Abdullah Saeed and Hassan Saeed, Freedom of Religion, Apostasy and Islam, Burlington VT: Ashgate Publishing Company, 2004, 10.

${ }^{49}$ Abdullah Saeed and Hassan Saeed, Freedom of Religion, Apostasy and Islam..., 1.

${ }^{50}$ Abdullah Saeed and Hassan Saeed, Freedom of Religion, Apostasy and Islam..., 2.
} 
a capital punishment for the apostasy at first was limited to a treachery, but then it is hijacked by those trying to apply it for the conversion case from or humiliation of Islam. ${ }^{51}$

In Saeed's perspective, there are many verses in the Quran that clearly state that there is no one that may be coerced to accept or to follow a belief or religion. According to him, the task of the Prophet and other important religious figures before Him is to deliver treatises, not to coerce anyone to accept the treatise. A theme "no coercion of a belief or religion" was very dominant during the revelation period of the Quran either in Mecca or in Medina. Especially, in Mecca the message of tolerance is very prominent. It does not mean that the message of the Quran changed when the Prophet moved to Medina and built a strong base for Islam.

In clarifying the individual freedom to choose, the Quran regards all people able to make a choice. This assumption is important since it gives a meaning to the choice. Human beings are given capabilities of choosing and knowing what is right and wrong. Form the Quran point of view, it is a unique thing for human beings among other God's creatures. Different from other creatures, human beings from the beginning are viewed as creatures are provided with abilities to make a moral choice and to be responsible for the choice. ${ }^{52}$ The Quran does not merely gives human beings a freedom of religion or belief, but also recognizes that different people follow different systems of belief and religion. The Quran respectfully refers to other religions, especially the "divine revelation religion” such as Jew and Christian. In some opportunities, the Quran suggests or advices skeptical Christians and Jews to return to their holy books to fund the truth. They are advised to solve their problems by referring to what is stated in their holy books. Moreover, the Quran states

\footnotetext{
${ }^{51}$ Abdullah Saeed and Hassan Saeed, Freedom of Religion, Apostasy and Islam..., 2-3.

${ }^{52}$ Abdullah Saeed and Hassan Saeed, Freedom of Religion, Apostasy and Islam..., 72.
} 
that those who believe in God and who do goodness will get rewards from God (5:69).

On the basis of an idea on the freedom of belief and a wider concept of the tolerance of religion, the Quran teaches that there is no coercion in religion and that it is fully up to individual to choose what religion one believes in. The Quran firmly states that it is not allowed to coerce others to accept Islam (2:256). This verse is very central in relation to the idea of the freedom of religion. Saeed cites opinions of an exegesis al-Suyuti who firmly states that there is no coercion in religion, based on various stories and historical events during and after the Prophet periods. A number of Muslim 'Ulama believe that the above-mentioned verses are merely related to ahl al-kitab (Jews and Christians) who may not be coerced to believe in Islam if they pay zakat (tithe), while other 'Ulama believe that this verse has been nullified (mansukh) by other verses that order Muslims to battle (qital). According to the latter, all people from all traditions of religions should be asked to believe in God, if they refuse to follow Islam or to pay jizyah, they should be fought against until they are killed. Most experts in law and in interpretation have the understanding. The verse that is considered to abrogate the QS 2:256 is the QS 9:123.

However, some cited stories show that a coercion may be used for Arabian who are polytheists, instead of ahl al-kitab. If this story may be accepted, it seems that the concept of the freedom of religion is a narrow concept and should be specifically applied. However, according to Saeed, this interpretation contains a serious problem because the Quran in various verses states that any coercion may not be made to ask other people to enter into Islam. A number of verses in the Quran (Mecca and Medina) stress that one may not be coerced to believe in God. This view seems to become a confusing permission to fight against unbelievers using powers to coerce them to believe in God. Fighting is allowed to protect the religion, 
belief, and region to fight against potential or real aggressions or to end any oppression or suppression, not to fight to ask other persons to change their religion (convert). There is no single verse stating that one may be coerced to believe in God or to enter into Islam. To have a religion or a belief is a voluntary choice. ${ }^{53}$

Exegetes such as al-Suyuti, al-Razi and even Sayyid Qutb give an emphasis on an opinion that there is no any coercion in religion, as firmly stated in the Quran. Qutb, for example, as cited by Saeed, states that the freedom of religion or of belief is the first human rights granting humanity to Man. Anyone who robs the rights to the freedom of religion means that he robs the humanity itself. ${ }^{54}$

The Quran does not allow any war aimed at conversion into Islam, but such a war is allowed under the context of attacking unbelievers who threatening the security or the safety of "Islamic state" that is newly established during the Prophet period. The Quran instructs Muslims not to fight unbelievers who had an agreement of peace with them or those who did not maltreated and did bad treatments to Muslims. ${ }^{55}$ There are verses of the Quran that instruct Muslims to "kill unbelievers" and it implies that it is merely the submission to the Prophet that may be accepted. The verses were revealed at the ending period of the prophecy and are related to the political situation the Muslim community had when the Muslims faced some non-Muslims who were still active to threaten them. There are some reasons to instruct the Prophet to fight against the unbelievers, "anywhere they were found". If the non-Muslims reached a superiority over the Muslims, they would (1) not respect the content or the conditions of the existing agreements of peace; (2) plan an eviction to the Prophet from Medina; (3) initiate to attack Muslims. The possible composite bad effects

\footnotetext{
${ }^{53}$ Abdullah Saeed and Hassan Saeed, Freedom of Religion, Apostasy and Islam..., 74.

${ }^{54}$ Abdullah Saeed and Hassan Saeed, Freedom of Religion, Apostasy and Islam..., 75.

${ }^{55}$ Abdullah Saeed and Hassan Saeed, Freedom of Religion, Apostasy and Islam..., 76.
} 
caused the Quran to instruct Muslims to be ready to battle, if necessary. ${ }^{56}$

The verses are command Muslims to fight against unbelievers refer to specific cases, and cannot be made as the base for stating that the freedom of belief in Islam was merely given at the early period of Islam when Islam was still weak, or that the freedom of religion is not intended to be applied for the whole time and condition. If the verses containing the instructions to fight against the unbelievers are understood as an abrogation (naskh) of the earlier verses on the freedom of religion, the result is to abrogate many verses that emphasise not only the freedom of religion but also the characteristic of the relationship between God and Men, and the important meaning of the sincerity of religion.

A thorough reading of the relevant texts of the Quran and hadith shows that there is no reason to believe that the freedom of religion is abrogated. There is no ay indication from the Prophet that the verses dealing with the non-coercion in the religion is nullified. There is a hadith or a verse in the Quran (like Letter 9) showing that almost at the end of the prophecy mission, the Prophet is expected to make use of force against certain groups namely the Arabian unbelievers or Christian and Jews. If it is intended to coerce them to accept Islam, the general principle that it is not allowed to coerce in religion should be rethought. There is no indication in the Quran, however, firmly stating that a coercive conversion become the end in itself. This verse merely appeared a response to the political demand and the security of Muslim community at that time. ${ }^{57}$

In a deep debate on human rights, one of the rights that becomes the target of criticism by Muslims is the right to the freedom of religion for their brothers, Muslims. The critics have an opinion that the freedom of religion for a Muslim as formulised in the human rights instrument is not

\footnotetext{
${ }^{56}$ Abdullah Saeed and Hassan Saeed, Freedom of Religion, Apostasy and Islam..., 77.

${ }^{57}$ Abdullah Saeed and Hassan Saeed, Freedom of Religion, Apostasy and Islam..., 78.
} 
in line with the norms, values and laws of Islam, and therefore it must be refused. Other Muslims view that the right to the freedom of religion is really relevant with the instruction of the Quran and the Prophet.

A thorough study of the discourse of human rights shows that at present, this discourse is not exclusively Western. Most Muslim countries, as the members of United Nations, principally accept the Universal Declaration of Human Rights and some even have ratified the main convention of human rights. Moreover, as a sign of participation in this discourse, some Muslims have developed what they consider as the document of Muslims' human rights. As a whole, the documents are modelled based on the UDHR or similar convention of human rights but they use ideas and terminologies of Islam and are often justified by the Quran texts.

In the history of the pre-modern Islamic law, the right to the freedom of religion was marginalised through irtidad or murtad laws and capital punishment for irtidad actions. Saeed elaborates the background of the legal formulation of murtad, especially in the political context and intraIslam intolerance playing important roles in the legal development. What is important is the high levels of diversities in understanding what apostate is, a condition used by political figures to control, to oppress, to suppress or to kill opponents. It is for this reason that the potential misuse of apostate law is very high through the history of Islam.

Saeed opposes an idea that the punishment appropriate for apostates is death sentence is based on a clear guidance of the Quran and hadith. He firmly states that there is no one verse in the Quran that justifies a temporal punishment to apostates, and there are few verses that justify some of the punishments to apostates dealing with them. Most laws to apostates are developed from ahad hadiths (transmitted by only one transmitter) and the interpretation of them or they are based on analogies and ijtihad. Since there is one law that guarantees the certainty of knowledge such as those 
understood in the Islamic jurisprudence principle, Muslims in this modern era have chances to rethink the laws. If the laws are not practiced anymore or irrelevant with Muslims, there is a strong justification to rethink the laws. An Argument that the laws are supported by ijma' may not hinder Muslims to agree with this. Various other laws with no consensus on the history of Islam are open to revise and in some cases are not used at all.

Dealing with the freedom of religion, it is clear that the Quran supports an idea of the freedom of religion and religious belief as personal (individual) choice. The freedom of religion is stated in the Quran in various contexts and ways. However, in interpreting the texts, the Muslim 'Ulama in the pre-modern period restricted the scope of the freedom available for a Muslim in choosing and adopting a religion or a system of belief. There chose a narrow definition of the freedom of religion, restricted it like the freedom given to the non-Muslims so that they were willing to be under the power of Islam as a protected minority (ahl aldhimmah) or they entered into Islam. For Muslims, once they became Muslims, converting their religion into other religions was not allowable. To avoid such conversion, the expert in Islamic law developed irtidad or murtad law into capital punishment as the highest punishment, justified based on the ahad hadiths.

By following Islam, an individual by himself became a part of the community of the people who believed in God. This community also functions as a political unit: khilafah or imarah. So, there is a meeting between a religious identity rooted in the society and a political identity. In general, since the concept was developed in the pre-modern Islamic law, if one refused the community by converting his religion into other religions, he automatically was also expelled from the political community. It means that he loses his basic rights as a person (right to live, right to have wealthy) given when he becames a Muslim. 
Since individual basic rights depend on "becoming a part of the community," an idea of apostasy and anything concerning with it at the pre-modern period may be understood. Whereas, most Muslims at present have shifted from a meeting between a religious community and a political identity to a division between the two. At present, political communities in terms of the nation-state should not be based on religious communities, and in fact most nation-states in this world, including the world of Islam, are not based on this strict identification. An individual may become a citizen of a political unit apart from his religious affiliation. ${ }^{58}$ It is a case happening in the majority of the Islamic state, where a modern constitution assures the freedom of religion and the equality before the law for all. Thus, the freedom of religion and of belief becomes the most principal right in this modern period to manage the state-nation. ${ }^{59}$

Therefore, a Muslim intellectual's thought which is represented by Abdullah Saeed, a prominent Muslim intellectual in Australia, strongly tends to support the right to the freedom of religion. His thought is based on his deep understanding on rich resources of classical Islam which are elaborated with the contemporary perspective of human rights. He concludes that supporting this right is inherently Islamic.

\section{Conclusion}

Muslims in Australia are undoubtedly minority. As minority, they have been living in a country that is secular and multicultural. In this context, the state has protected the right to the freedom of religion of its citizens. It is because the state ratified several international human

${ }^{58}$ Although Muslims should deal with practices of secularism mainly in terms of national citizenship, their religious identity cannot be totally neglected. See Nasya Bahfen, "The Individual and the Ummah: The Use of Social Media by Muslim Minority Communities in Australia and the United States," Journal of Muslim Minority Affairs, Volume 38, Issue 1 (2018), 119-131.

${ }^{59}$ Abdullah Saeed and Hassan Saeed, Freedom of Religion, Apostasy and Islam..., 169. 
rights documents, such as UDHR and ICCPR. Consequently, it has supported the implementation of human rights laws in its legal and territorial boundaries. In the practical level, state administrators have also been consistently recognised of their professionalism towards the law enforcement. Although Muslims have faced discriminations from political actors of a fundamentalist group of a minority Christian, Muslim leaders have involved in the religious education of Muslim communities and have disseminated ideas of religious tolerance, interreligious dialogues, pluralism and freedom of religion. ${ }^{60}$ One of prominent Muslim intellectuals, Abdullah Saeed, has understood that the implementation of the right to the freedom of religion is important to guarantee the security of Muslims. He has believed that human rights and the rights of the freedom of religion are essential parts of basic principles of Islam, in addition. Thus, this article argues that while Australia has protected, respected and fulfilled the freedom of religion of its all citizens, at the same time, it supports the development of Ummah. However, the social and political situation that has happened in Australia is dynamic. So, what will happen in the future regarding the minority Ummah in the country, has remained to be seen.

\section{Bibliography}

Akbarzadeh, Shahram and Abdullah Saeed. Muslim Communities in Australia. Sydney: University of New South Wales, 2001.

Akbarzadeh, Shahram, "The Muslim Question in Australia: Islamophobia and Muslim Alienation," Journal of Muslim Minority Affairs, Volume 36, Issue 3 (2016): 323-333.

Arifin, Syamsul, "Indonesian Discourse on Human Rights and Freedom

\footnotetext{
${ }^{60}$ Conceptually, it is essential to consider Mohd Yaseen Gada, "On Pluralism, Religious 'Other', and the Quran: A Post September-11 Discourse," Indonesian Journal of Islam and Muslim Societies, Volume 6, Number 2 (2016), 241-271.
} 
of Religion or Belief: Muslim Perspectives," Brigham Young University Law Review, Volume 1, Issue 3 (2012): 775-808.

Arifin, Syamsul. Attitudes to Human Rights and Freedom of Religion or Belief in Indonesia. Yogyakarta: Kanisius, 2010.

Australian Human Rights Commission, "Chart of Australian Treaty Ratifications as of May 2012.” Accessed April 22, 2018. https://www. humanrights.gov.au/chart-australian-treaty-ratifications-may-2012human-rights-your-fingertips-human-rights-your.

Australian Human Rights Commission, "Freedom of thought, conscience and religion or belief." Accessed April 22, 2018. https://www. humanrights.gov.au/freedom-thought-conscience-and-religion-orbelief.

Bahfen, Nasya, "The Individual and the Ummah: The Use of Social Media by Muslim Minority Communities in Australia and the United States," Journal of Muslim Minority Affairs, Volume 38, Issue 1 (2018): 119-131.

Barry, James and Ihsan Yilmaz, "Liminality and Racial Hazing of Muslim Migrants: Media Framing of Albanians in Shepparton, Australia, 1930-1955," Ethnic and Racial Studies, Volume 42, Issue 7 (2019): $1168-1185$.

Busbridge, Rachel, "It's Just Your Turn: Performing Identity and Muslim Australian Popular Culture," Islam and Christian-Muslim Relation, Volume 24, Number 4 (2013): 459-477.

Cherney, Adrian and Kristina Murphy, "Being a 'Suspect Community' in a Post 9/11 World - The Impact of the War on Terror on Muslim Communities in Australia," Criminology, Volume 48, Issue 4 (2016): 480-496.

Cleland, Bilal. The Muslim in Australia: A Brief History. Melbourne: Islamic Council of Victoria, 2002. 
Colic-Peisker, Cal, Masha Mikola and Karien Dekker, "Religious

Visibility: Perceptions and Experiences of Residents in Two Muslim

Concentration Suburbs in Melbourne, Australia," Ethnic and Racial Studies, Volume 42, Issue 15 (2019): 2743-2762.

Dunn, Kevin M., Natascha Klocker and Tanya Salaby, "Contemporary

Racism and Islamophobia in Australia: Racializing Religion,"

Ethnicities, Volume 7, Number 4 (2007): 564-589.

Fanani, Ahmad Fuad, "Menjadi Muslim Minoritas di Negara Sekuler:

Refleksi dari Australia,” Prisma, Volume 29 (2010): 72-82.

Farrar, Salim, "Profiting from Shari'a: Islamic Banking and Finance in Australia," in Adam Possamai, James T. Richardson, Bryan S. Turner (eds.) The Sociology of Shari'a: Case Studies from around the World. London: Springer, 2015: 269-289.

Gada, Mohd Yaseen, “On Pluralism, Religious 'Other', and the Quran: A Post September-11 Discourse," Indonesian Journal of Islam and Muslim Societies, Volume 6, Number 2 (2016): 241-271.

Harris, Anita and Kim Lam, "Youth Participation in 'Post]Secular' Times:

Young Muslim and Buddhist Practitioners as Religious Citizens," The British Journal of Sociology, Volume 70. Issue 2 (2019): 627-646.

Hopkins, Liza, "Muslim Turks and anti-Muslim Discourse: The Effects of Media Constructions of Islamic and Arabic in Australia," Australian Journal of Communication, Volume 35, Number 1 (2008): 41-55.

Humphrey, Michael, "An Australian Islam?: Religion in The Multicultural City," in Abdullah Saeed and Shahram Akbarzadeh (eds.). Muslim Communities in Australia. Sydney: UNSW Press, 2001: 33-52.

Hussein, Jamila, "Muslim Family Law in Australia: Conflicting or Compatible," in Samina Yasmeen (ed.). Muslims in Australia: The Dynamics of Exclusion and Inclusion. Melbourne: Melbourne University Press, 2010: 204-228. 
Lewis, Jeffrey, Philip Pond, Robin Cameron, and Belinda Lewis, "Social Cohesion, Twitter and Far-Right Politics in Australia: Diversity in the Democratic Mediasphere," European Journal of Cultural Studies, Volume 22, Issue 5-6 (2019): 958-978.

Lindholm, Tore, W. Cole Durham, Jr., and Bahia G. Tahzib-Lie (eds) Facilitating Freedom of Religion or Belief: A Deskbook. Leiden: Koninklijke Brill NV, 2004.

Mansouri, Fethi and Matteo Vergani, "Intercultural Contact, Knowledge of Islam, and Prejudice against Muslims in Australia," International Journal of Intercultural Relations, Volume 66 (2018): 85-94.

Mansouri, Fethi, "Citizenship, Identity, and Belonging in Contemporary Australia," in Shahram Akbarzadeh and Samina Yasmeen (eds.). Islam and the West: Reflections from Australia. Sydney: UNSW Press, 2005: 149-164.

Mirmoosavi, Ali, “The Quran and Religious Freedom” in Bas de Gaay Fortman, Kurt Martens, and MA Mohamed Salih (eds.). Hermeneutics, Scriptural Politics, and Human Rights. New York: Palgrave Macmillan, 2009: 125-142.

Mirza, Abdul Malik and Abdel-Karem Halabi, "Islamic Banking in Australia: Challenge and Opportunities," Journal of Muslim Minority Affairs, Volume 23, Number 2 (2003): 347-359.

Murphy, Kristina, Natasha S. Madon and Adrian Cherney, "Reporting Threats of Terrorism: Stigmatisation, Procedural Justice and Policing Muslims in Australia," Policing and Society, An International Journal of Research and Policy (2018): 1-17.

Nowak, Manfred and Tanja Vospernik, "Permissible Restriction on Freedom of Religion or Belief," in Tore Lindholm, W. Cole Durham, Jr., and Bahia G. Tahzib-Lie (eds.). Facilitating Freedom of Religion: A Deskbook. Leiden: Koninklijke Brill NV, 2004: 147-172. 
Peucker, Mario, "Islamophobia and Stigmatising Discourses: A Driving Force for Muslim Active Citizenship?" in Esposito J., Iner D. (eds.). Islamophobia and Radicalization. Cham, Switzerland: Palgrave Macmillan, 2019: 245-264.

Poyning, Scott and Victoria Mason, "The Resistible Rise of Islamophobia: Anti-Muslim Racism in the UK and Australia Before 11 September 2001," Journal of Sociology, Volume 43, Number 11 (2007): 61-86.

Prime Minister, "Protecting Freedom of Religion in Australia: Media Release 14 December 2017.” Accessed April 22, 2018. https://www. pm.gov.au/media/protecting-freedom-religion-australia.

Reid, Donald, "Sharing the Halal Snack-Pack: Multiculturalism as Neoassimilation in Australia," Journal of Media and Cultural Studies, Volume 22, Issue 1 (2019): 77-92.

Saeed, Abdullah and Hassan Saeed. Freedom of Religion, Apostasy and Islam. Burlington, VT: Ashgate Publishing Company, 2004.

Saeed, Abdullah, "Muslim Australians: Their Beliefs, Practices and Institutions," Department of Immigrant and Multicultural and Indigenous Affairs and Australian Multicultural Foundation in Association with the University of Melbourne, 2004.

Saeed, Abdullah. Islam in Australia. Sydney: Allen \& Unwin, 2003. Schottmann, Sven Alexander, "Being-Muslim in Australia, ca. 2013," Islam and Christian-Muslim Relation, Volume 24, Number 4 (2013): 419-425.

United Nations, International Covenant on Civil and Political Rights, 1966. Accessed April 25, 2016. https://www.un.org/ruleoflaw/blog/ document/international-covenant-on-civil-and-political-rights/.

United Nations, The Declaration on the Elimination of All Forms of Intolerance and Discrimination Based on Religion or Belief, 1981. Accessed April 25, 2018. http://www.un.org/documents/ga/res/36/a36r055.htm. 
IJIMS: Indonesian Journal of Islam and Muslim Societies, Volume 9, Number 2, December 2019: 295-326

United Nations, The Universal Declaration of Human Rights, 1948. Accessed April 25, 2018. http://www.un.org/en/universal-declaration-humanrights/.

Van Der Ven, Johannes A. Human Rights or Religious Rules?. Leiden: Brill, 2010.

Wardana, Amika, "Institutionalising Diasporic Islam: Multiculturalism, Secularism and the Integration of Muslim Immigrants in Britain," Indonesian Journal of Islam and Muslim Societies, Volume 3, Number 1 (2013): 31-72.

Woodlock, Rachel, "Praying Where They Don't Belong: Female Muslim Convert and Access to Mosque in Melbourne, Australia," Journal of Muslim Minority Affair, Volume 30, Number 2 (2010): 265-278.

Yasmeen, Samina, "Understanding Muslim Identities: From Perceived Relative Exclusion to Inclusion," Centre for Muslim State and Societies, University of Western Australia, May 2008. Accessed April 22, 2018. http://www.web.uwa.edu.au/__data/assets/pdf_ file/0010/1138582/Understanding_Muslim_Identities.

Yucel, Salih, "Is Islam Part of the Problem or Solution: An Australian Immigrant Experience?” Turkish Journal of Politics, Volume 2, Number 1 (2011): 136-152. 